\title{
GESCHIEDENIS VAN DE NEDERLANDSCHE BOVENWINDSCHE EILANDEN IN DE 18DE EEUW
}

DOOR

\author{
PROF. DR. L. KNAPPERT \\ HOOFDSTUK VII (Slot)
}

$\S 14$. Wij hebben op het einde van § 11 gemeld, dat Alexander Le Jeune De Graaff als secretaris opvolgde. Anthony Beaujon, ons reeds bekend, werd toen eerste klerk op $f 40$ 's maands ${ }^{1}$ ). $\mathrm{Zij}$ konden het samen slecht vinden en ook de verhouding tusschen Le Jeune en De Graaff was verre van hartelijk, zooals wij reeds in ander verband aanstipten ${ }^{2}$ ). De botsing tusschen beide ambtsdragers liep wel is waar voor een groot deel over nietigheden, maar het verhaal ervan zal ons toch de toestanden en de verhoudingen op ons eiland in deze kritieke jaren beter doen kennen.

Le Jeune kon blijkbaar niet op tegen de cabale van Commandeur en Raden, die zich souverein noemden en van oordeel waren, dat het de Heeren weinig kon schelen hoe de zaken gingen, wanneer zij maar hunne gerechtigheden ontvingen. Doch onderling was het ook alles behalve vrede, zoodat b.v. de commandeur den raadsheer Dirk Groeneveld door een korporaal en soldaten van zijn bed had doen lichten en ,in de prison plakken”. Daar de man alleen Engelsch kende, vroeg hij om een procureur, wat hem geweigerd en hijzelf aan boord van een schip naar Montserrat gezonden werd. Een arme jood, die had durven zeggen, dat De Graaff niet lang meester van het gouvernement zou zijn werd, bijna omgekomen van honger, naar St. Thomas verbannen. Een andere jood kreeg 25 pes. boete omdat hij tweeden Pinksterdag (19 Mei in 1777) een langen broek had verkocht aan een matroos, die naar boord ging, terwijl de commandeur onder kerktijd zijn

1) Heeren $X$ aan De Graaff 24 Mei 1776. In 1779 zou Beaujon, bij afwezigheid van De Graaff, het secretariaat waarnemen, $\mathrm{X}$ aan Runnels 18 Mei 1779, 111 W.I.C. 74.

2) Boven deel XII 580 . 
huis liet verven en zijn negers langs de straat stroop en cassavebrood verkoopen. Aldus is geen burger meer zeker in zijn huis, geen planter op zijn plantage ${ }^{1}$ ). Maar C. en R., vertoornd over dergelijke aantijgingen, die hij niet onder zich gehouden had, ontzegden den secretaris zitting in hun college en benoemden in zijne plaats Anthony Beaujou den eersten klerk ${ }^{2}$ ).

In onze bronnen bevinden zich nu voorts een aantal bezwarende getuigenissen tegen De Graaff, door Le Jeune van onderscheiden burgers bijéén verzameld en naar patria opgezonden. De waarheid ervan vaststellen is niet wel mogelijk; alle te zamen werpen een kwaad licht op het leven daarginds. Wij kunnen niet bij alle stilstaan. Getuigenis leggen o.a. af mevrouw Cath. Doeke Groebe, wed. Nic. ten Tooren, James Johnson Brown, medicinae doctor, Hendrik Matthias Evertsz. le klerk en gevangen, P. la Clotte, vertegenwoordiger bij procuratie van J. Jacques Audier te Bordeaux e.a. Er zijn stukken van weinig beteekenis als een Engelsch van Catharina Keesom, door Matthew Murphey, „not having the grace of God before his eyes", beticht van „,being got with child by mr. Nicholas Dawes". De man herroept alles bij acte voor Le Jeune en nu weigert De Graaff het stuk aen Catharina terug te geven $\left.{ }^{3}\right)$. Er is een zeker sujet, Fred. George Bopp, die in gezelschap vertelt, dat hij eens als klerk op de secretarie te Paramaribo een testament voor eene Indiaansche vrouw zou passeeren, zich onderweg met biljard spelen had opgehouden en, aan het huis der vrouw gekomen, haar dood had gevonden; dat hij toen aan de doode een pen in de hand had gegeven, die vastgehouden en dat de vrouw aldus toch nog haar testament geteekend had. Het gezelschap noemde dit terecht een infaam stuk, en men begrijpt alleen niet, hoe Le Jeune er waarde aan kon hechten, dat zoo iemand den commandeur voor een dief uitgemaakt en gezegd had, dat hij en de raden „verdoemde canailles” en „kaale blixems” waren ${ }^{4}$ ).

Van meer belang is een brief van genoemden Evertsz. aan Le Jeune uit fort Oranje d.d. 23 Juli 1777. Hij vertelt dat den vorigen dag iemand van het benedenfort bij den busschieter van fort Oranje, Pieter, een kardoes kruit van twee pond kwam halen. Pieter had het kruithuis opengemaakt en in een leege kardoes

\footnotetext{
1) Le Jeune aan X 23 Juli 1777, boek 5, fol. 212, 219, 223, 224, 234, 235. Het gansche lijvig adres fol. 210-237.

2) Resolutie van C. en R. 9 Mei 1777, boek 5, fol. 239. Le Jeune aan H.H. Mog. 25

Juli 1777, aldaar fol. 335-339.

s) Boek 5, fol. 255. 257-259 Eng., 261-264 Ned.

4) Boek 5, fol. $317-319$.
} 
twee maten kruit gedaan uit een vat dat vlak bij de deur van het kruithuis zonder deksel, dus open, stond, terwijl de deur heel verrot was. Evertsz. zelf had aan den avond van dienzelfden dag den zoon van den commandant, Gerard, met eene brandende lont op de de batterij ontmoet en hem gesmeekt daar vandaan te gaan ${ }^{1}$ ). Pieter had hem uitgelegd, dat het kruithuis zoo vochtig was, dat zij daar geen kardoezen konden bewaren. Hij hield ze dus in zijn huis en, wanneer er dan geschoten moest worden, gingen zij de kardoezen in het kruithuis vullen. De Graaff weigerde echter alle herstel, omdat de kas der Compagnie dat niet toeliet. Eens was de commandeur bij nacht aan het fort gekomen en toen had Ravené hém het wachtwoord gegeven! Evertsz. had toen gezegd: „hoe is dat mogelijk? De commandeur moest u het parool gegeven hebben om binnen te komen en dat zou zelfs voor den Prins gelden, wanneer hij 's nachts in het fort wilde wezen." Waarop Ravené geantwoord had: „de commandeur geeft het parool uit, ik heb het van hem ontvangen en moet het hem teruggeven." Dus, besluit Evertsz., wie maar zegt, dat hij de commandeur is, al ware het de vijand, die kon 's nachts binnen het fort komen ${ }^{2}$ ).

In een reeds vroegeren brief aan Heeren X, van 15 Januari 1777, had Le Jeune nog het volgende verteld. Kapitein Andries Eckman van het schip De Expeditie had 3 Januari aan De Graaff bericht, dat Matthijs Hendrik Zeyen den avond te voren in een herberg hem had gezegd, dat zijn kajuitwachter, Jonas Arenberg, hem op oudejaarsavond had willen vergeven. Deze man, toen in hechtenis genomen, was 8 Januari voor den Raad verschenen en De Graaff had tot hem, den suppliant, gezegd: „Vriendje, ziet gij dat wel", wijzende op een takel, waaraan men de verdachten opheesch om hen te doen bekennen, ,,daar zullen wij u wel mede doen klappen, je bent een doortrapte knaap." Le Jeune was den volgenden dag bij den commandeur binnen gegaan en had hem onder het oog gebracht dat er veeleer zware verdenking tegen den aanbrenger moest rijzen, vermits Arenberg, weder met den takel gedreigd, geroepen had: ,,al moet ik sterven, ik kan niet anders dan bekennen dat Zeyen zelf het mij voorgeslagen heeft!' Zaterdag 11 Januari was het toen in den Raad tot hevige standjes tusschen Le Jeune èn den commandeur met zijne raadsheeren gekomen. Inderdaad werd Arenberg opgeheschen, de handen op

\footnotetext{
1) Er waren toen Abr. Ravené, de vader en commandant van het garnizoen, de zoons, Johan korporaal, Andries sergeant en Gerard constabelmaat.

2) Boek 5, fol. 327-329. Origineel.
} 
zijn rug gebonden met een kogel om zijn hals, maar hij bleef ontkennen ${ }^{1}$ ).

Al deze stukken, naar patria opgezonden, en voor C. en R. zoo bezwarend noopten dit college tot verweer. Zij verklaarden aan de Heeren dat zij, om het wangedrag des heeren Le Jeune het roer der regeering met hem niet langer konden houden. Door hem waren zij tegenwoordig op ieders tong, tot hoon en spot van het publiek. Niet uit animositeit tegen zijn persoon handelden zij, maar op beterschap konden zij niet meer hopen bij dezen man. Intusschen beloofden zij dat De Graaff bij behouden arrivement in het vaderland - hij zou immers daarheen vertrekken - alles mondeling zou toelichten ${ }^{2}$ ). Daarop hebben de Heeren echter niet gewacht, maar gelastten Le Jeune zijn leedwezen te betuigen en te vragen om opheffing zijner schorsing. Daarna moest alles vergeten en vergeven zijn. Doch dat wilden C. en R. niet, om hun eigen eer en om de rust en vrede van het eiland. Volgens hen moest de zaak voor H.H. Mog. komen en middelerwijl bleef Le Jeune geschorst en Beaujon secretaris a. i. ${ }^{3}$ ). Wel is waar stond de secretaris den 11 den Februari nog eens binnen en overhandigde een memorie aan De Graaff en zekere reservatie en protestatie, maar nieuws bevatten ze niet. Blijkbaar hield men 's mans zaak slepende. Le Jeune van zijn kant hield die vergadering van den 11 den Februari voor onwettig, ,alzoo het gewoone insigne namentlijk dat de vlagge van de forteres, wanneer dezelve vergadert sijn, niet heeft gewaeyt." 4)

$\S 15$. Een paar maanden later geschiedde er erger. Den 7den April 1778 was het raadslid Joh. Heyliger overleden, Maandag 13 April zou in fort Oranje de verkiezing van een opvolger uit het gewone, door de burgerij aangeboden, dubbeltal plaats hebben. De commandeur (dus nog niet naar patria vertrokken) verzocht van de pui van het raadhuis den burgers hunne stemmen uit te brengen. Le Jeune maakte zich gereed de stemmen te gaan opnemen. De Graaff verbood het hem. Toen hij: „dan zal er in het geheel geen stemming zijn!' De burgerij komt in beroering, er

1) Le Jeune aan X 15 Januari 1777, boek 5, fol. 341-352, 375. Er staat knippel kogel, hetgeen ik niet heb kunnen thuis brengen.

a) C. en R. aan X 12 Febr. 1778, boek 5, fol. 446-449.

3) Missive van representant en bewindhebberen 3 Nov. 1777, gelezen 6 Febr. 1778, boek 5 , fol. $450-453$.

4) Boek 5, fol. 454. De beide ingeleverde stukken fol. 456-459. De begeleiding fol. 460-464. Nog 7 Maart 1778 schrijft Le Jeune dat C. en R. hem niet in zijn ambt willen herstellen vór de zaak door H.H. Mog. „finaal is gedecideerd”, boek 5, fol. 501. C. en R. waren toen Joh. de Graaff, Joh. Heyliger (maar 7 April zou hij overlijden), Pieter Runnels, Oliv. Oyen, Dirk Salomonsz. en Jac. Seys. 
ontstaat luid tumult en luitenant Willem Heyliger roept: „de secretaris moet de stemmen opnemen, wij willen het altemaal!" De Graaff ging toen uit de forteres naar zijn huis. En wie woonden dit relletje bij? Wij hebben verhaald van het eskader van Van Bylandt in deze wateren ${ }^{1}$ ). De schout-bij-nacht lag onder St. Maarten, wilde gaarne de verkiezing bijwonen en was Zondag 12 April in alle haast naar ons eiland gekomen, vergezeld van de heeren Willem van Braam en Jan Pruyst ${ }^{2}$ ). Thans, getuige van het tumult, verliet van Bylandt het raadhuis, voegde zich onder de burgers en toonde hun duidelijk zijn ,faveur”. Voor C. en R. was dit stellig onaangenaam, vooral ook omdat hij zeide geen particuliere orders te hebben. Le Jeune, vermoedde De Graaff, had zich bij hem ingedrongen. Ook waren de secretaris en luitenant Heyliger vroeger vijanden. Nu werden Herodes en Pilatus vrienden. O tijden, $\mathrm{O}$ zeden, verzuchtte De Graaf in zijn relaas aan de Heeren ${ }^{3}$ ).

Vrijdag 17 April vroeg toen van Bylandt met C. en R. te mogen vergaderen. Thans had hij behalve weder van Braam en Pruyst nog Guilliam van Harencarspel Dekker bij zich, geen kapitein in zijn eskader. Na een langdurig gehaspel over de aanwezigheid van Beaujon, las van Bylandt eene memorie voor, dat C. en R. zelven aanleiding tot het tumult gegeven hadden, dat er stemmen waren gekocht, dat op den verkiezingsdag twee met kleine kogels geladen kanonnen op de batterij hadden gestaan gereed tot vuren. Van Bylandt weigerde copie te geven. C. en R. wenschten toen geen verdere particuliere conferentie meer met hem, maar gelastten dat Le Jeune, behoorlijk geassisteerd, zich uit hun naam bij den schout-bij-nacht zou vervoegen en hem aanzeggen, dat de memorie, ten vorigen dage door hem voorgelezen hen grootelijks had ,geledeert en gegraveert”. Dit waren serieuze zaken en zij eischten thans nog eens copie en de namen van Van Bylandts berichtgevers. Ook moest Le Jeune hem „op regtelijke en solemnele wijse" afvragen of hij particuliere orders kon toonen, want $\mathrm{C}$. en $\mathrm{R}$. waren immers alleen verantwoording schuldig aan hunne heeren en meesters en aan H. H. Mog. $\left.{ }^{4}\right)$.

Aldus ging Le Jeune ten huize van den koopman Jacques Tex-

1) Boven $\S 13$.

${ }^{2}$ ) In genoemd eskader commandeerde kapt. W. van Braam de Thetis en Jan Pruyst de Brunswijk.

3) Joh. de Graaff aan X 25 April 1778 boek 5, fol. 530-535. Over de gehechtheid der burgerij aan hun privileges in zake de dubbeltallen boven XI 525 .

4) C. en R. aan X 15 en 17 April 1778, boek 5, fol. 540-544, 547-550, 551 - 553. 
ier, waar Van Bylandt logeerde. Hij echter liet antwoorden, dat C. en R. niet bevoegd waren om zijn persoon, als tot beveiliging der kolonie en van den handel uitgezonden, eenig molest aan te doen met zulke insinuatiën. Hij zou ten eersten zijne mesures nemen om verdere onheilen en verwarring te vóórkomen, weigerde verder copie en zou nader schriftelijk antwoorden ${ }^{1}$ ). En hij deed het. „Met uiterste surprise heb ik mij gisteren door den Secretaris gemolesteerd gevonden met uwe insinuatie, waardoor met verwondering bespeure een minagting aan het caracter, dat ik bij den souverein onzer republicq bekleede, aangedaan. Zal mij bij den souverein beklagen. Treed in niet de minste discussie omtrent de ongehoorde demarches dewelke ik bevonden heb te exteeren. Ik zal ook mijne reflectiën maken dat, toen wij vergaderden, U.E.A. mij genoegsaam hebben willen dwingen om daarbij den 1sten klerk te admitteeren, met wien ik niets te doen had, en door debatten wie er present en wie niet present zouden zijn ben ik een geheele poos opgehouden. Het smart mij dat U.E. Achtbaarens zig aangetrokken hebben dat wat mij volgens algemeene gerugte ter oren gekomen was. Nergens anders om aangeroerd als om U.E.A. te kennen te geven dat tot maintien van U.E. goede naam en faam het de pligt was om de schuldigen ten rigoureuste te vervolgen. Maar ik vinde daarvoor geen obligatie, en U.E.A., in plaats van kragtige middelen tegen het kwaad te beramen, schijnen geledeert, bejegenen mij met bitsheid en oplopendheid. Zulke gerugten komen mij suspect voor $\left.{ }^{2}\right)$. Gelieven U.E.A. zig dit persoonlijk aan te trekken, ik zal er mij niet tegens opponeeren. Het zal mij aangenaam zijn te vernemen dat U.E.A. door de magt die U.E.A. in handen hebt de lasteraars zult straffen in plaats van mij zulks af te vergen, hetgeen de ongerijmdheid zelve is, alzo ik van honderde menschen, waarvan ik er geen bij naam ken, diergelijke dingen gehoord heb. Teffens vind ik ook zeer impoliet en onbescheiden van U.E.A. om mij bij insinuatie af te vragen copie van een discours, dat ik voor mijn geheugen ter nedergesteld had, ben verwonderd dat U.E.A. mij niet ordonneeren volgens den toon, die deselve met mij gelieven te houden, om mijn discours in geschriften over te geven. De burgers blijven gepriveert van het regt dat sij altoos hebben gehad om hun stemmen door den secretaris op te laten nemen. Geene vrije stemming aldus volgens de wetten en art. 5 van de instructie van den gouverneur. U.E.A. representeerend de Hoofden van

1) Verklaring van Le Jeune, boek 5, fol. 553, 554.

2) D.w.z. hebben mijn argwaan gewekt. 
een vrij volk moesten alles doen tot mainteneering van soo een privilegie en andere welke reeds door den Commandeur ontnomen zijn en tot mainteneering van welke U.E.A. verzekert kunt sijn dat ik kragtdadige middelen in het werk zal stellen. Verder heb ik geen explicatie van mijn orders aan U.E.A. te geven ${ }^{1}$ ).

Ziedaar het stuk van den schout-bij-nacht, die, vermoed ik, orders zal gehad hebben op de gedragingen van De Graaff toe te zien, wiens eigenmachtig optreden, ook in de Amerikaansche aangelegenheden, controle wenschelijk maakte ${ }^{2}$ ). Dat tijdens de verkiezing twee kanonnen van de groote batterij, met kogels geladen, gereed stonden, daaromtrent legden een aantal burgers, die de Hollandsche taal niet machtig waren eene verklaring af, dat zij den avond te voren, zich bevindende op het Scandal Hall, zijnde eene kleine, overdekte plaats bij het opkomen van den berg aan het oude pad, door Abr. Ravené den zoon hoorden verzekeren, dat die kanonnen gereed stonden. Hij had er nog bijgevoegd, dat er ook soldaten in drie "plottons" met geladen geweren tot vuren gereed stonden. Daartegenover verklaarde Ravené de vader, dat de commandeur alleen had bevolen alarm te schieten om de burgers ter verkiezing bijéén te roepen. En Joh. Godet constabel met Sören Jaeger constabelsmaat voegden daar nog bij, dat er geen kanonnen met schroot geladen waren, noch verplaatst noch gebakst ${ }^{3}$ ) en dat zij ook geen orders ontvangen hadden. C. en R. zelven eindelijk beweerden dat genoemde jeugdige Ravené bij zijn verhoor door de mand was gevallen en gezegd had dat „zulks alleen maar raillerie en een praatje geweest was" 4).

Bij resolutie van Woensdag 15 April, Zondag 19 in de kerk voorgelezen, bepaalden C. en $\mathrm{R}$. Woensdag 22 voor de nieuwe verkiezing van een raadslid en Vrijdag 24 voor die van een kapitein der burgerij. Wel is waar protesteerden daartegen 105 burgers als strijdig met de aloude en ,welbewuste" privilegies o.a. dat het hun verboden werd met hunne geweren in fort Oranje te verschijnen ${ }^{5}$ ), maar de verkiezing ging deze maal door, Hendrik

1) Van Bylandt aan C. en R. 18 April 1778. Geauth. copie. Boek 5, fol. 563-566.

2) Van Bylandt, De Graaff als hoogste gezaghebber vervangend en op zijn neutraliteit een wakend oog houdend, bij Franklin Jameson $a . w$. pag. 694. Over de vrees voor een dergelijk maritiem oppergezag (van kapitein later vice-admiraal Corn. Schrijver) boven XII 177.

s) Baksen d.i. een kanon met handspaken verzetten.

4) Verklaring der burgers 16 April 1778, boek 5, fol. 555-556. Idem van Abr. Ravené 18 April, aldaar fol. 557. Idem van Godet en Jaeger 18 April, aldaar fol. 559 Idem van sergeant Abr. Heyliger Pzn. 18 April, aldaar fol. 501. C. en R. als boven fol. 550 .

s) Protest van 105 burgers 22 April 1778, boek 5, fol. 567-569. Zeer vele Engelsche namen. Met zijn geweer in het fort verschijnen, ook een oud privilege boven XI 363. 
Pandt werd raadsheer, Pieter Runnels kapitein der burgerij. Op dien Woensdag waren de schout-bij-nacht met zijne kapiteinen, luitenant Willem Heyliger en Le Jeune met nog vele anderen vergaderd geweest in het wachthuis dicht bij het fort, gewapend met geweren, ofschoon dat immers verboden was. In dit alles zagen C. en R. dwarsboomen der regeering ${ }^{1}$ ).

$\S 16$. De commandeur had intusschen zijn vroeger vermelde reis naar het vaderland aangevangen, waar hij althans Juli aankwam $^{2}$ ). Aanstonds hebben toen de Heeren de zaak van hem en Le Jeune ter hand genomen en reeds in de volgende vergadering van C. en R. was er bericht. Le Jeune stond binnen en las een geschrift voor, waarin hij een hartelijk leedwezen over het gebeurde betuigde en verzocht om de schorsing op te heffen. De commandeur a. i. deelde hem daarop mede dat er orders waren gekomen om hem in zijn ambt te herstellen en dat zijne schade zou vergoed worden. Daarop Le Jeune, dat dit beide partijen niet behoefde te verhinderen de actie tegen elkander voort te zetten. Dan weer Runnels dat er geene reconciliatie te pas kwam, alleen opvolgen van de bevelen der meesters. Daarop nam de secretaris zijn oude plaats in ${ }^{3}$ ). Hij leverde eene memorie in, waarin hij zijne verliezen aan leges, emolumenten enz. berekende op 2123-3-2 pesos. En ontving 353-7-1 $\frac{2}{3}$ pes. ,zijnde $\frac{1}{6}$ vant geen mij is competeerende ${ }^{4}$ ". Nog bleek, dat de Heeren het afkeurden, dat De Graaff sinds den dood van fiskaal Joh. Meyer dat ambt zelf had waargenomen en zij benoemden daarom tot fiskaal van St. Eustatius en Saba Mr. Joh. Lambert ter Hoeven op 100 dukaten 's jaars. Zij hoopten dat daardoor ook de klachten over de langdurigheid der procedures zouden ophouden en wenschten dat men de wijze van procedeeren van Curaçao navolgen zou ${ }^{5}$ ).

$\S 17$. Wij moeten ook nog de toestanden op St. Maarten beschouwen. Albert van Heyningen vroeg ontslag als secretaris met dit beding dat zijn eenige zoon hem mocht opvolgen ${ }^{6}$ ). En zoo geschiedde ook. De vader herinnerde er nog aan, dat zijn zoon, thans dus secretaris-vendumeester, hem van 1741 tot 1778 zonder gage had geholpen, zoodat er thans wel eenige renumeratie

\footnotetext{
1) Brief van De Graaff als boven 25 April 1778, boek 5, fol. 537-538.

$\left.{ }^{2}\right)$ Franklin Jameson a.w. pag. 694 .

3) Los catern, ongepagineerd, boek 5 , na fol. 569 .

4) $T \cdot a \cdot p$.

5) Heeren X aan C. en R. 30 April, 1 Mei, 28 Juni 1778. Enkele jaren later, na de groote ramp, bepaalden zij dat de fiskaal evenals in Demerary en Essequebo zitting in den Raad zou hebben als fiskaal-adviseur met rang na den commandeur, 15 Oct. 1784112 W.I.C. 75.

6) Alb. van Heyningen aan X 20 Aug. 1777, 28 Jan. 1778, boek 5, fol. 579, 496.
} 
voor hem mocht overschieten. „U.ED. gelieven te noteeren dat wij in deze landen zoo min van de lugt leven als U.E.Gr. A. a costy." ") In plaats van Albert jun. werd Hendrik van Rhijn gezworen klerk.

Henricus Godet vroeg concessie voor 30 jaar om de zoutpan te ontginnen. Maar de ingezetenen verzochten haar niet te verhuren, omdat zij immers gemeen eigendom was. De Heeren waren hen ter wille, maar onder het natuurlijk beding dat zij dan ook voor het onderhoud moesten zorgen ${ }^{2}$ ).

„Wij kunnen van de lucht niet leven”, zeide Albert v. Heyningen. Inderdaad zag het er op St. Maarten treurig uit, sinds den Amerikaansch-Engelschen oorlog was er schier geen invoer en alles duur en schaarsch. De prijzen der gewone levensmiddelen waren vóór en na dien oorlog, alles in pesos, meel per vat 8 à 9 en 17 à 18 , spek 12 à 13 en 20 à 24 , vleesch 6 à 8 en 15 à 18 , bakkeljouw per honderd pond 3 à 5 en 7 à 8 , rijst 4 à $4 \frac{1}{2}$ en $6 \frac{1}{2}$ à 7 , haver 3 à 4 en 8 à 10 . Paarden vroeger 40 à 60 thans 80 à $120^{3}$ ). En wat was er van het moederland te wachten? Met ingehouden ergernis meldde de vice-commandeur de aankomst op 26 November 1777 van twaalf militairen, onder wie drie oude en afgeleefde, twee kinderen en één gebochelde, alle twaalf zonder eenige monteering, patroontasch of zijdgeweer ${ }^{4}$ ). In dit laatste werd eenigszins voorzien doordat De Graaff drie maanden later per Juffrouw Alida, schipper Cornelis Jansz. Hofker, 24 volle monteeringen ontving, waarvan hij er 12 naar St. Maarten doorzond ${ }^{5}$ ). Doch hoe kon men verwachten met zulk een garnizoen de neutraliteit te kunnen handhaven? Kort te voren had zich weder zulk een lastig geval voorgedaan.

Nadat Donderdag 27 November 1777 een Engelsche kaper een Amerikaanschen schoener onder het geschut van St. Maarten genomen had, kwam Vrijdag 26 December van dat jaar des avonds buiten Grootbaai een brigantijn ten anker met drie andere kleinere vaartuigen. Het bleek daarna de Revenge, voerende de Amerikaansche vlag, kapitein La Roche. Een officier van dien bodem meldde zich bij den vice-commandeur, die hem natuurlijk zijne verwondering te kennen gaf, dat hij zijne prijzen in eene Hollandsche haven dorst brengen en hem gebood aanstonds zee te kiezen.

\footnotetext{
1) Heeren X aan Abr. Heyliger 22 Juni 1778. Alb. van Heyningen aan X 17 Febr. 1780, 452 W.I.C. 634

2) Heeren X aan Abr. Heyliger Pzn. 10 Mei 1780, 112 W.I.C. 75.

3) Abr. Heyliger aan X 17 Oct. 1777; boek 5, fol. 382. Staatje van levensmiddelen aldaar fol. 385.

4) Abr. Heyliger aan X 24 Jan. 1778, boek 5, fol. 407.

5) Joh. de Graaff aan X 1 April 1778, boek 5, fol. 526.

West-Indische Gids XIV 
Doch daarop adresseerde zich aan Heyliger ook nog Thomas Alloway, kapitein van een der genomen Engelsche kapers, die zeide dat hij en zijn volk zeer vriendelijk waren behandeld en dat de Amerikaan hem had beloofd personen en goederen vrij te zullen geven. En of hij tot morgen blijven mocht. De vice-commandeur stond hem dat toe ,uit vriendelijkheid". Doch den volgenden morgen, Zaterdag 27 December, moest hij zien, dat de Amerikaan den kaper van Alloway onttakelde en mast en boegspriet omkapte. $\mathrm{Na}$ zulk eene beleediging gaf Heyliger aanstonds last op hem te schieten. Toen hij het gebeurde aan de Heeren berichtte, legde hij meteen een aantal verklaringen over, waaruit bleek dat hij waarlijk op den Amerikaan geschoten had. Want daarop zou het aankomen, indien de Engelschen zouden klagen. Zoo getuigde dan Joseph Wyeth, „gunner" (kanonnier) van het fort, dat de vicecommandeur hem den 27sten December bevolen had een schot op de Revenge te lossen, toen ten anker onder Point Blanche, de uiterste punt van Grootbaai, door het kanon van fort Amsterdam bestreken ${ }^{1}$ ). Charles Chadwich en Jacob Diaz Delagado, burgers van St. Maarten, zwoeren, de een „bij de heilige evangelisten van Almighty God", de ander bij de Vijf boeken van Mozes, dat zij de schoten hadden zien vallen. Michael Cuviljé, burger van St. Eustatius, maar toen op St. Maarten, Louis Charles Bodwell, kapitein Dirk Peeper van het fregat d'Eendragt, allen ooggetuigen, verklaarden dat er van het fort continueel gevuurd was en dat er althans drie kogels bij de brigantijn gevallen waren, die straks de ankers gelicht had ${ }^{2}$ ).

En de klachten kwamen inderdaad. Generaal Burt van Antigua wendde zich tot De Graaff, en Heyliger dacht, dat hij dit ook wel in Den Haag zou doen. Burt schreef ook aan Heyliger op hoogen toon. Hij kon alleen klachten over Engelsche handelingen in ontvangst nemen van den commandeur van St. Eustatius, van wien Heyliger immers afhankelijk was. Doch hij wilde wel zeggen, dat hij ten zeerste ontstemd was over de bescherming, door onze eilanden verleend aan de rebellen tegen zijnen Koninklijken meester. Wat in Europa niet mag, is ook in de West-Indiën niet geoorloofd. Men bespeurt, dat St. Maarten lijden moest onder den boozen naam van St. Eustatius. Grievend was ook, dat Burt Heyliger afhankelijk noemde van De Graaff. Het was een oud zeer. In zijn genoemden brief over de aftandsche militairen had hij zich juist weer beklaagd over De Graaff die zich alle gezag aanmatigde, ter-

1) Vergel. boven XIII 182 vlg. 187.

2) Abr. Heyliger Pzn. aan X 5 Febr. 1778, boek 5, fol. 409-412. De in den tekst genoemde verklaringen aldaar fol. $424,428,430,438,440-444$. 
wijl toch immers alleen in zake van appel op vonnissen St. Maarten aan St. Eustatius ondergeschikt was ${ }^{1}$ ).

$\S 18$. En thans zijn wij genaderd tot het smartelijk relaas van den ,gruwel der verwoesting”. Wij zijn nog op St. Maarten. Nadat begin April 1779 de Engelschen de bark Fanny onder het geschut der eilanden genomen hadden ${ }^{2}$ ); nadat 8 Juli 1780 de Engelsche schoener Hawke weder een Amerikaansch schip op een pistoolschot afstand van Point Blanche veroverd had; verscheen, als een voorspel van het Statiaansche drama, den 9den Augustus 1780 des morgens ten 9 ure een Engelsch eskader voor St. Maarten. Het bestond uit het schip van linie Cyclope, kapitein Robinson, 28 st. en de zes fregatten Convert, kapitein Hervy, 32 st.,; Intrepid, kapitein Holly, 64 st. ; Fortune, kapitein Christian, 42 st. ; Hornett kapitein Pitt, 16 st.; Rover, kapitein Savage, 16 st. en Surprise, kapitein Day, 16 st. Twee officieren roeiden aan wal en zeiden te zijn gekomen om alle Amerikaansche schepen en lading prijs te maken volgens orders van admiraal Rodney. $\mathrm{Zij}$ verwachtten geen tegenstand en zouden de opgezetenen geen letsel doen, maar, zoo er ook maar één schot op hen gelost werd, zouden zij dorp en fort in de asch leggen. Heyliger antwoordde dat, indien zij hostiliteiten pleegden, hij de Amerikaansche eigendommen beschermen zou; waarop weder de officieren, dat de macht aan hen was en zij aanstonds hunne orders zouden uitvoeren. De Raad des eilands besloot een protest tot den bevelhebbenden officier te richten en daarmede gingen enkele heeren aan boord van het vlaggeschip Cyclope. Natuurlijk zonder gevolg. Bij zoo groote overmacht scheen het voorzichtig het eiland voor schade te bewaren - met drie Amerikaansche schepen zeilde het eskader weg, was 11 Augustus bij St. Eustatius en bleef daar kruisen. De Amerikaansche vaartuigen aldaar, gewaarschuwd, hadden nog juist kunnen ontkomen. De tabak die op St. Maarten, bij gebrek aan pakhuisruimte, aan den wal lag, lieten de Engelschen weer vrij, ofschoon zij uit Amerika kwam. De opgezetenen hadden haar gekocht en betaald ${ }^{3}$ ).

$\S 19$. Den 6den Februari 1778 was het verdrag tusschen Frankrijk en Amerika geteekend. Op den 16den November 1779 namen

1) Abr. Heyliger Pzn. aan X als boven, boek 5, fol. 413, 414. William Matthew Burt aan Heyliger d.d. Antigua 2 May 1778 (er staat bij vergissing 1777), aldaar fol. 422. Heyliger aan X 24 Jan. 1778 aldaar fol. 405, 406.

2) Heeren $\mathrm{X}$ aan Runnels (toen nog comm. a.i.) 18 Mei 1779, 111 W.I.C. 74. De in den tekst te noemen schoener Hawke misschien genoemd naar baron Edward Hawke 1705-1781, admiraal, maar sinds 1759 niet meer in zeedienst, Encycl. Brit. 11 e ed. XIII 95, 96. Of eenvoudig Hawk, valk.

3) Abr. Heyliger Pzn. aan De Graaff 9 Aug. 1780, get. door A. van Heyningen jun. secr. De Graaff aan X 12 Aug. 1780, 452 W.I.C. 634. 


\section{NEDERLANDSCHE BOVENWINDSCHE EILANDEN}

binnen kanonschot van de forten van St. Eustatius Engelsche kapers drie Fransche schoeners. Dit wekte weder verbittering tegen ons van die zijde. Bij missive van 28 Februari 1780 beklaagde Paul François de Quelen, hertog de la Vauguyon, sinds December 1776 Fransch gezant in Den Haag, zich over de bescherming welke De Graaff aan die Engelsche kapers zou verleend hebben ${ }^{1}$ ). Engelsche, Fransche klachten - wat konden schout-bij-nacht Willem Crull en Frederik Sigismund van Bylandt ${ }^{2}$ ) met hun twee oorlogsbodems daartegen doen? Temidden van al deze troebelen kwam de vreeselijke orkaan van October 1780 en verwoestte tal van huizen, terwijl honderden menschen het leven lieten. In die maand volgde de gevangenneming van Henry Laurens, onder wiens papieren de Engelschen een Hollandsch-Amerikaansch verdrag vonden, twee jaren oud, wel is waar slechts een on-officiëel ontwerp, maar dan toch geteekend door een agent van het congres en een van de stad Amsterdam ${ }^{3}$ ). Yorke eischte de exemplaire bestraffing van Van Berkel en de zijnen als verstoorders van den vrede, maar ,in de Republiek was het moeielijker eene oproerige stad te straffen dan nu voor de Amerikaansche regeering den moord van Italianen in New Orleans" "). Het antwoord was zóó ontwijkend, dat Yorke Den Haag verliet. De oorlogsverklaring van Engeland volgde 20 December 1780.

En in den vroegen morgen van Zaterdag 3 Februari 1781 vertoonde zich schout-bij-nacht Sir Samuel Hood met zijn eskader aan den gezichteinder, 's middags één uur volgde Rodney, in het geheel 15 schepen van linie en 5 fregatten ${ }^{5}$ ). Generaal John Vaughan was generaal der landingstroepen. Daartegenover hadden wij het fregat Mars van Van Bylandt, 250 man en 36 stukken en op het fort een garnizoen van op zijn hoogst 50 man! Toch hadden Heeren X nog 3 Maart 1781, toen nog onkundig van de ramp, de

1) „Les François qui naviguent et commercent à St. Eustache au lieu d'y éprouver des traittements conformes aux lois de la justice et de la neutralité, se plaignent au contraire d'une partialité marquée et d'une protection ouverte accordée aux Anglais que le commandant semble se plaire à favoriser." Heeren X aan De Graaff 10 Maart 1780,452 W.I.C. 634.

2) Frederik Sigismund, graaf van Bylandt, 1749-1828 was een oomzegger van den boven genoemden Lodewijk, met van Kinsbergen de hervormer onzer vervallen marine, Regt in N. Ned. Biogr. Woordb. IV 377 vlgg.

3) Colenbrander a.w. I 132, 182.

4) Franklin Jameson a.w. pag. 697.

5) Behalve de boven in het begin van $\S 12$ noot genoemde literatuur en bronnen ken ik nog den brief van een ooggetuige, Catharina Doeke Groebe, wed. Nic. ten Tooren (die wij reeds ontmoetten als getuige à charge tegen De Graaff, boven § 14) aan Mich. van der Meulen op Curaçao d.d. 19 Nov. 1781, voor een goed deel afgedrukt bij Teenstra $a . w$. II 344 vlg. 
brutale naïveteit gehad om aan De Graaff te schrijven dat zij vast vertrouwden, dat hij alles zou aanwenden wat noodig was tot verdediging van de bezittingen der Compagnie. Om de bespotting volkomen te maken zonden zij meteen.... tien kaperbrieven à $f$ 15-11-0 per stuk.

Doch niet voor niets had Yorke 7 November 1780 aan Lord Stormont geschreven, dat de genadeslag ons het best in de West kon worden toegebracht, waar de goudmijn onzer macht lag ${ }^{1}$ ). Thans eischte Rodney de overgave. Hij schreef: ,Sandwich off the harbour of St. Eustatius 3 Februari 1781. Sir! We the general officers, commanding in chief His Brittannic Majesty's fleet and army in the West-Indies, do in his royal name demand an instant surrounder of the island of St. Eustatius and its dependencies with every thing in and belonging thereto. We give you an hour from the delivery of this message to decide. If any resistence is made you must abide the consequences. Brydges Rodney. John Vaughan". Tegenstand, ach arme! Zelfs het eenige fregat, Bylandts Mars, fel beschoten door de Resolution, later ook (schoon Rodney dat niet had bevolen) door de Gibraltar en de Prince William, was genoodzaakt de vlag neder te halen. Van Bylandt bracht zijn degen op het admiraalschip ${ }^{2}$ ). Amerikaansche matrozen hebben een poos in het binnenland tegenstand geboden, maar tegen Vaughans troepen tevergeefs. Joh. de Graaff, Oliver Oyen, Jac. Seys en Hendrik Pandt gaven het eiland over en bevalen het aan in de genade van Rodney en Vaughan, ,well knowing the honor and humanity of the two commanders".

$\S 20$. Het linieschip ${ }^{3}$ ) van Willem Crull, ook Mars geheeten, van 34 stukken, was juist uitgezeild ter convoyeering van 30 koopvaarders. Rodney zond hem de Monarch, de Panther en de Sybil achterna, in den ongelijken strijd werd het convooy genomen en Crull sneuvelde na heldhaftigen tegenstand - de eerste doode in den oorlog. Rodney meldde zijn dood in gepaste termen en liet hem met eerbewijzen begraven. Fenger zag op het oude kerkhof, waar de De Windts, de Heyligers, de Mussenders begraven liggen,

1) „It is in the West Indies that the most immediate reprisal might be made and which would affect them the most, because it is the golden mine of the moment and in the working of which the greatest members are actually employ'd", bij Colenbrander a.w. I 388 .

2) Nederl. Jaarboeken 1781, blz. 787 vlgg. Aanteekeningen van Van Bylandt bij De Jonge, a.w. IV 460 vlg. Dat de kapiteins der Gibraltar en der Prince William door Rodney in arrest werden gesteld, hier en ook in den boven genoemden brief van Mevr. de wed. ten Tooren.

$\left.{ }^{3}\right), \ldots \ldots$ of the Line as they call everything upon which they can place about fifty guns", Yorke bij Colenbrander, a.w. I 389. 
het graf des admiraals, met geen enkel gedenkteeken om voor de wereld van zijn heldenmoed te gewagen. "Wat doet het er toe, daar de wereld hier nimmer voorbijgaat" ${ }^{1}$ ).

Den 5den Februari zond Rodney naar St. Maarten twee schepen van linie en twee fregatten onder kapitein Thomson met 500 man troepen onder kolonel Edhouse. De overmacht was groot genoeg en het half uur bedenktijd niet noodig. De soldaten bedreven velerlei moedwil, in de kerk o.a. braken zij den mahoniehouten preekstoel en de banken aan stukken. Ds. Reneman, sinds 24 October 1779 op het eiland, hield toen godsdienstoefening in zijn huis. Dat hij in die booze dagen ook St. Eustatius bediende, hebben wij gezien ${ }^{2}$ ).

Met St. Eustatius ging ook Saba over. Na Pieter Simonsz. was daar in 1778 Thomas Dinsey vice-commandeur geworden ${ }^{3}$ ).

$\S 21$. Langer dan een maand liet Rodney nog de Hollandsche vlag van het fort waaien, zoodat nog telkens koopvaarders van allerlei natiën, onwetend van het gebeurde, argeloos binnenliepen en den buit nog vermeerderden. Wij hebben vroeger gezien dat in één maand, Juli 1779, 384 schepen binnen liepen en 400 uitgingen ${ }^{4}$ ). Dat was er sedert niet minder op geworden en het verbaast ons niet, dat Rodney, zooals hij aan zijn vrouw schreef, al aanstonds 130 koopvaarders buit maakte, waarbij dan nog dagelijks die andere komen. De rijkdom aan goederen, in de pakhuizen, ja daarbuiten op het strand opgestapeld, was ontzaglijk. Naar matige schatting lag daar voor een waarde van $3.000 .000 £$. Doch dit was niet alles. Rodney had het eiland een addernest genoemd, dat de strengste kastijding verdiende, een toevluchtsoord voor wie aan elke misdaad schuldig stonden, een herberg van het uitschot der natiën, zonder eenig recht op eene gewone capitulatie. Hij zou toonen dat de gerechte wraak van een beleedigd Engeland mis-

1) Rodney aan Phil. Stephens d.d. 4 Febr. 1781 bij Fenger, Alone in the Caribbean pag. 303 alwaar ook zijn in den tekst geciteerde uitroep. Een foto van het graf tegenover pag. 392. De Jonge a.w. IV 463-468 met portret des admiraals. Ad Patriam, in funere fortisfimi herois Gulielmi Crullii. Lugd. Bat. apud P. Pluygers 1781. Bibl. Thys., Catal. III no. 7061. Zijn schip bleek zóó slecht gebouwd, dat de onderste batterij met de monden der stukken onder water dook. Ook Teenstra, a.w. II 332: „De schout-bij-nacht Krull .... werd in het gouvernementsgraf ten noorden van den kerktoren bijgezet. Men vindt echter geen inscriptie die zijnen naam of verdiensten vermeldt." Wordt het niet hoog tijd daarin nog te voorzien? Ook al komt de wereld hier nimmer voorbij?

${ }^{2}$ ) Reneman aan X 27 Oct. 1781 door bezorging van Albert van Heyningen. Abr. Heyliger Pzn. aan X 10 Sept. 1782, 452 W.I.C. 634. Boven XII 427, 435. De vicecommandeur heeft de ramp nog twee jaren overleefd, hij zou 23 Juli 1783 aan de pokken overlijden, 65 jaar oud.

3) Missiven van X 1 Mei 1778, 112 W.I.C. 75 .

•) Boven XIII $188 \mathrm{vlg}$. 
schien langzaam maar in elk geval zeker was, en hij hoopte het eiland te verlaten als niets dan eene woestenij, waarvan men later alleen bij hooren zeggen nog iets zou weten ${ }^{1}$ ). Zoo had dan eene algemeene verbeurdverklaring aller goederen op 18 Februari plaats, zonder onderscheid van Nederlandsch en Engelsch, neutralen en eigen onderdanen, rijken en armen, kooplieden en arbeiders. Alle Europeesche goederen werden van 15 Maart tot begin Mei voor den Koning verkocht, zoodat de Amerikanen hier goedkoop scheepsbenoodigdheden konden inslaan! Andere scheepsvictualiën gingen naar Antigua, het archief met alle papieren werd verbrand, de benedenstad grondig verwoest. Finis Trojae. En privatim stalen de Engelschen het geld uit de zakken der burgers, groeven in de tuinen naar verborgen schatten, mishandelden de slaven, vernielden het huisraad ${ }^{2}$ ).

In het vaderland was de verslagenheid groot en algemeen en de woede tegen de Engelschen uitte zich ook in menig gedicht. Van een sonnet Het Schrikgedrocht geef ik de zes laatste regels:

„Welk is het beest dat, tuk op rooven en vernielen,

Niets met meer blijdschap doet dan plond'ren en ontzielen

En zwakken dreigen met een bliksemend gebit?

Welk is het schrikgedrocht, dat het geslacht der menschen

Met zooveel billijkheid naar zijnen val zal wenschen?

Geen ander dan de snoode en godvergeten Brit". ${ }^{3}$ )

En in een curieus boekje vind ik bij een fraai prentje van de plundering dit versje:

„Geeft Britten aan Vaughan's en Rodney's goddeloosheid

De schoonste namen ter bedekking hunner boosheid,

$\mathrm{Ik}$, die hun wreed gedrag met afschrik gadesla,

Noem Rodney Nero en Vaughan Caligula." "4)

Het is waar dat Fred. Sig. van Bylandt in zijne aanteekeningen zegt, dat de plunderingen en gewelddaden op ons eiland wezenlijk

\footnotetext{
1) Zie ook Rodney aan Lady Rodney in Mundy, Life and Correspondence of Lord Rodney II 97. Voorts Franklin Jameson a.w. pag. 702.

$\left.{ }^{2}\right)$ Men zie nog Gazette de Leyde 27 Maart, 17 April, 8 en 15 Mei, 3 Juli, 1781. Nederl. Jaarb. 1781 blz. 807, 813, 1225-1227. Voorts de plaatsen bij Franklin Jameson $a . w$. pag. 704. Zegen rustte niet onverdeeld op dien buit. De Fransche admiraal La Motte Piquet veroverde bij Brest 25 met goederen zwaar geladen schepen, die van St. Eustatius naar Engeland voeren.

3) Vóóraan in een gedrukte verzameling van de door Rodney en Vaughan geproclameerde ordonnanties, collectie-Hamelberg, Kon. Bibl.

4) Het reeds boven blz. 564 noot 1 genoemde Engelsche tieranny, Amst., Gartman, 1781 tegenov. blz. 96 .
} 
op rekening kwamen van den zoo aanstonds nog te noemen kolonel Cockburne, den vertrouwde van Vaughan, en dat zijne landslieden hem daarom vervloekten als een schandvlek hunner natie $\left.{ }^{1}\right)$. Maar het is ook waar dat Rodney, een speler en telkens in zware schulden, op oorlogsbuit zijn hoop gevestigd had en zonder gewetensbezwaren er zijn eigen fortuin en dat zijner familie uit opbouwde ${ }^{2}$ ).

$\S 22$. In Engeland was de vreugde zoo groot en uitbundig als de verslagenheid hier, maar in het House of Commons interpelleerde de oppositie, bij monde van Edmund Burke, de regeering over de ongehoorde strengheid des admiraals. Rodney verdedigde zich zoo goed hij kon en eene commissie van onderzoek werd niet benoemd ${ }^{3}$ ). Den 12den April 1782 zou hij den grooten en befaamden zeeslag bij Les Saintes, tusschen Dominica en Guadeloupe, winnen tegen den Franschen admiraal De Grasse en daardoor bij zijne landgenooten de heugenis van zijn fouten als mensch uitwisschen $\left.{ }^{4}\right)$.

Wij keeren nog een oogenblik naar ons eiland terug. Rodney dan was midden 1781 naar Engeland onder zeil gegaan. Op St. Eustatius droeg hij het bevel over aan den brigadier-generaal David Ogilvy en de kolonels Cockburne (boven genoemd) en Stafford. Ogilvy overleed reeds 31 Mei en sinds voerde Cockburne het gezag Toen geschiedde het, dat in den nacht van 24 op 25 November 1781 drie Fransche fregatten onder den markies De Bouillé van Martinique kwamen, troepen landden, die de wacht van fort Oranje verrasten en het garnizoen van 600 man krijgsgevangen maakten, onder wie ook Cockburne. Ook St. Maarten en Saba werden hernomen ${ }^{5}$ ). Bij den vrede van Parijs 20 Mei 1784 kwamen zij aan Nederland terug. Doch St. Eustatius, ontvolkt door de vlucht van tallooze kooplieden naar St. Thomas, waarheen zich de handel verplaatste (en het Nederlandsch door de immers veelal

1) Bij De Jonge, a.w. IV 462 noot 2.

2) Encycl. Brit. eleventh ed. 1911, XXIII 447-448. Daarin „R. was vain, selfish, unscrupulous in seeking prize money and in using his position to push the fortunes of his family." En Fenger $a, w$, pag. 258: „Rodney at this time was sixty-three years old" (geb. 1718, overl. 1792) „a roué, a gambler and crippled with gout”.

s) Parliament-acts Dec. 1781 pag. 627-630, on the confiscations at St. Eustatia. Onder de buitgemaakte goederen waren er vele van Engelsche kooplieden, die hem deswege processen aandeden. Nog in 1888 noemt James Anthony Froude, The English in the West Indies, Lond., Longmans, pag. 13 Burke met zijne interpellatie als een voorbeeld van den noodlottigen invloed van redenaars op 's lands zaken.

4) Froude, a.w. pag. 27-31. Aan het einde van de beschrijving van dezen zeeslag: "So on that memorable day was the English Empire saved."

$\left.{ }^{5}\right)$ An authenticated copy of the proceedings on the trial of Lt. Col. Cockburne for the loss of the island of St. Eustatius Lond. 1783. Daarvan een copie onder de papieren van Hamelberg 120 B. 4 Kon. Bibl. 
Engelsch sprekende Statianen achteruit gedrongen werd); ontvolkt ook door de beruchte wegvoering der Joden op 13 Februari 1781 naar St. Kitts; St. Eustatius „heeft sedert nooit meer iets beteekend" '1). Al te zwaar had de schrikkelijke slag getroffen.

$\S 23$. Ik ben hiermede aan het einde dezer studie gekomen. Volgens mijn in den beginne aangegeven bestek zou het jaar 1781, dat inderdaad het bloeitijdperk der eilanden afsluit, het eindpunt zijn. Naar mijn beste weten heb ik mijn geschiedverhaal uit de tallooze ongedrukte bescheiden opgebouwd. Een belangstellend lezer schreef mij dat het geen verheffenden indruk maakt. Dat doet het ook niet. Er is veel gekrakeel over kleinigheden, het grootsche, ontzagwekkende ontbreekt te veel. Ook de Heeren X vertoonen zich in hunne kortzichtigheid en in hunne verwaarloozing van de duurste belangen onzer eilanden. Wel terecht zeide mijn vriend Van Blom indertijd, dat het niet bij voorbaat vast stond, dat mijn werk dankbaar werk zou blijken $\left.{ }^{2}\right)$. Doch ik was al de jaren, dat ik met dezen arbeid bezig was, doordrongen van de krachtige overtuiging, dat ook de misschien weinig aangrijpende bladzijden onzer geschiedenis behoorden geschreven te worden, maar bovenal dat wij aan dit onaanzienlijk deel des Koninkrijks een zware schuld goed te maken hebben. Ik mag zeggen, dat mij dit voortdurend voor oogen heeft gestaan. Daarnaast vlei ik mij met de hoop, dat ik op de internationale verhoudingen onzer eilanden eenig licht geworpen heb; nog meer, dat ik geen twijfel heb overgelaten aan de gehechtheid ook toen van onze eilanders aan het moederland, dat hen toch zoo stiefmoederlijk bejegende.

Zal de ongunst der tijden nochtans toelaten dat uit deze studiën een boek groeit? Dat zou beteekenen herstel van begane fouten, kaarten, prenten, een immers hoognoodig register. Mijne illusies daaromtrent zijn gering, het onderwerp (om van de behandeling te zwijgen) kan maar de belangstelling van weinigen trekken. Moge dan deze studie, zooals zij is, de vrienden onzer Bovenwindsche Eilanden in hun liefde versterkt hebben en van het onbekende dat onbemind maakt bij anderen iets hebben weggenomen. Aan de Redactie van den West Indischen Gids ten slotte mijn hartelijken dank voor hare gastvrijheid, die ik moet vreezen ernstiger op de proef te hebben gesteld dan zij van te voren heeft kunnen vermoeden.

Oestgeest, 31 October 1931.

1) Nuchter maar waar Colenbrander a.w. I 191.

2) D. van Blom in De Gids 1930 I 302. 